\title{
Multi-decadal Changes on the Mud-dominated Coast of Western French Guiana: Implications for Mesoscale Shoreline Mobility, River-mouth Deflection, and Sediment Sorting
}

\author{
Morgane Jolivet (1), Antoine Gardel (1) et Edward Anthony (1,2) \\ USR 3456 LEEISA, CNRS Université de Guyane, IFREMER, Cayenne, French guiana \\ UMR CEREGE, Aix-Marseille Université, CNRS, IRD, INRA, Coll France, Aix-en Provence, France
}

\begin{abstract}
Mud supplied by the Amazon River forms large banks that migrate along the Amazon-Orinoco Guianas coast under the influence of waves and currents, separated by 'inter-bank' zones (phases). Bank-welding onto the coast creates new land, followed by rapid mangrove colonization, and westward deflection of the mouths of the smaller rivers. A fine example is Pointe Isère, a mud cape that deflected the mouth of the Mana River in French Guiana. During inter-bank phases, higher wave energy can result in rapid and massive shoreline erosion, except where sandy-shelly cheniers develop from winnowing of coarse-grained bedload from the surrounding muddy matrix. In order to contribute to a better understanding of the rates and scales of shoreline change on the French Guiana coast, we conducted a GIS analysis on Pointe Isère using a $>60$-year record of aerial photographs and satellite images. The results show significant and quasi-continuous erosion of this mud cape at the multi-decadal timescale. A phase of massive retreat of the shoreline (>1 km between 1955 and 1972), was followed by much slower erosion up to 2015, probably due to: (1) the alongshore passage of several mud banks, and (2) the formation of a sandy chenier through concentration, by waves, of contemporary sand of fluvial origin stored in the inner mud-dominated shoreface, and of sand derived from erosion of an old inland chenier exposed as a result of shoreline retreat. The new chenier has also been characterized by a westward-elongating spit. The progressive demise of Pointe Isère finally resulted, in 2001, in a breach that created a new direct outlet for the Mana River, and sealing of the former outlet through downdrift distal spit welding onshore. Over the study period (1955-2017), the demise of Pointe Isère has involved a loss of $41.8 \mathrm{~km} 2$, much of it mangrove wetlands. This corresponds to about 8\% of the total area of mangroves in French Guiana in 2015. Since 2015, a new phase of large-scale muddy accretion has been associated with the on-going isolation of the active sandy chenier. This probably heralds a new cycle of mud-cape formation in the vicinity of the mouth of the Mana that will lead to a new westward diversion of this river. During the continuous erosion of Pointe Isère, the longshore passage of several mud banks did not mitigate or counter erosion. This has important implications regarding the unpredictability of shoreline change on the Amazon-Orinoco coast, and the need to go beyond the common vision of such change in terms of mud-bank (shoreline accretion) and inter-bank (shoreline erosion) phases that cover timescales of the order of years to a decade.
\end{abstract}

ADDITIONAL INDEX WORDS: Mud bank, mud cape, chenier, mangroves, Amazon River, Guianas coast.

\section{INTRODUCTION}

The coastal plain of French Guiana (Figure 1) is part of the mud-dominated Guianas coast of northern South America between the Amazon and the Orinoco River deltas. Between these two large river mouths debouch several much smaller rivers. The Amazon is the world's largest river system and has a drainage basin of $6.1 \times 106 \mathrm{~km} 2$. Mud supplied by the Amazon has dominated the geological development of this coast. The resulting sediment accumulation pattern has been one of significant progradation along much of the $1500 \mathrm{~km}$ of coast between the Amazon and the Orinoco deltas, including French Guiana, over the last 5-6000 years, since sea level reached about its present position. Much of this progradation has occurred through onshore welding of mud derived from massive mud banks that migrate from the Amazon. The mud-bank system is unique in the world as a result of the extremely large and pervasive supply of mud by the Amazon (Anthony et al., 2010; Anthony, Gardel, and Gratiot, 2014; Augustinus, 1978; Augustinus, Hazeloff, and Kroon, 1989).

The mud banks migrate alongshore within a narrow belt under the influence of waves (Gratiot, Gardel, and Anthony, 2007). The French Guiana coast is affected by trade winds from the northeast (Augustinus, 2004) that are mainly active from January to May. These winds generate rains on the coast from December to July, with an intervening relatively dry month in March. The annual rainfall in the coastal zone varies from 2 to $3 \mathrm{~m}$. Trade winds are also the main generators of east to northeast waves from the North and Central Atlantic Ocean affecting this coast (Figure 1). Waves have significant periods ( $\left.T_{s}\right)$ of 6 to $10 \mathrm{~s}$, and significant offshore heights $\left(H_{s}\right)$ of 1 to $2 \mathrm{~m}$, the longer periods $(>8 \mathrm{~s})$ being associated with short spates of large swell waves generated by North Atlantic storms in autumn and winter and by Central Atlantic cyclones in summer and autumn. Tides are semi-diurnal and the spring tidal range in French Guiana is microtidal to low-mesotidal (about 1.5 to $3 \mathrm{~m}$ ).

Up to 20 mud banks, spaced at intervals of 15 to $25 \mathrm{~km}$, migrate at any time along the coast between the Amazon and the Orinoco at rates of 1 to $5 \mathrm{~km}$ a year (Gardel and Gratiot, 2005). The interval between banks is of the order of 10-20 years, and is not determined by fluctuations in the mud supply of the Amazon, which is pervasively high, but by coupled atmosphericoceanographic interactions involving changes in trade wind intensity and their effect on the waves generated by these winds (Gratiot, Gardel, and Anthony, 2007; Walcker et al., 2015). Such changes in wind intensity at timescales of several decades are very likely related to the North Atlantic Oscillation (NAO). By inducing variations in wind speed, the NAO influences the rate at which mud banks migrate, and this has consequences on the dynamics of the coast (Walcker et al., 2015). Once formed, mud banks migrate alongshore under a continuous process of reworking and transport by waves. This migration is assured by wave dissipation, and by wave- and wind-induced currents. The correlation between waves and the migration of mud banks, is, however, affected by other factors, including the angle at which waves attain the coast, the presence of rock outcrops along the coast, as in French Guiana, and the effect of river flow (Anthony et al., 2010). Long-term (>multi-decadal) coastal accretion ensuing from mud banks tends to imprint a northwest deflection of the mouths of the smaller rivers on the coast. This has been 

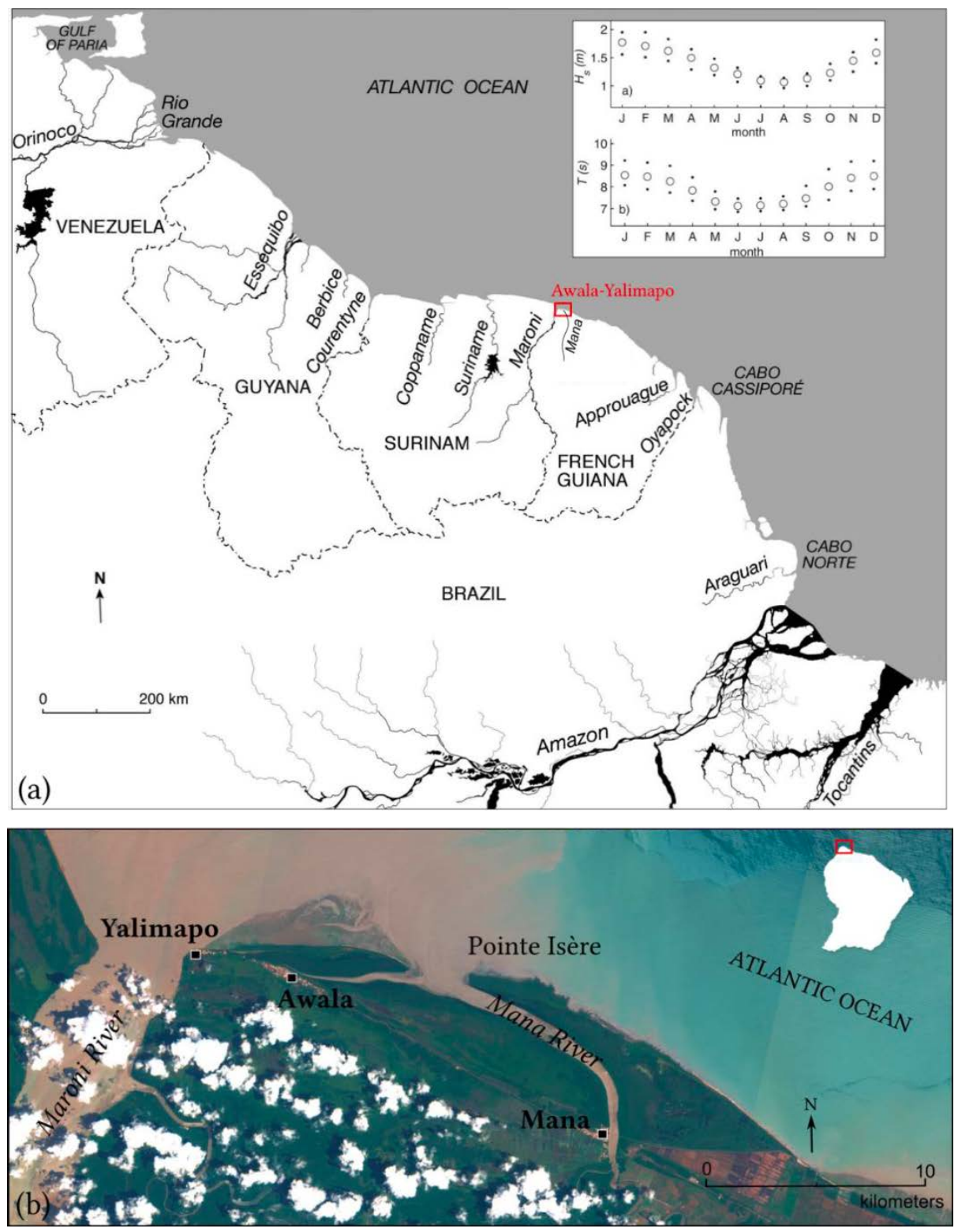

Figure 1. (a) Map of the Guianas coast between the deltas of the Amazon and Orinoco Rivers. Also shown are several smaller rivers, including the Mana in western French Guiana. Inset (from Gratiot, Gardel, and Anthony, 2007) shows daily averages of wave-climate parameters, $H_{s}$ and $T_{s}$, derived from a 44-year record of the ERA-40 (European ReAnalysis) wave dataset generated by the European Centre for MediumRange Weather Forecasts (ECMWF) for the location $5^{\circ} \mathrm{N}, 52^{\circ} \mathrm{W}$. Dots correspond to the first and third inter-quartiles, and circles to the median values. (b) SENTINEL2 satellite image showing the DYNALIT long-term coastal observation site straddling the settlements of Awala and Yalimapo, western French Guiana, in 2017. Pointe Isère, a mud cape extant since at least the mid-19th century, and the object of the study reported here, has been largely eroded over the last 60 years

the case of the Mana (Figure 1), a small river in western French Guiana with a catchment of 12,090 km2. This deflection commonly generates a more or less prominent mud cape colonized by mangroves. Such mud capes form robust coastal features throughout the coast of the Guianas and commonly incorporate sandy cheniers isolated inland. The capes generally provide shelter from direct attack by ocean waves coming from the northeast.

An erodible inter-bank area occurs in the wake of the trailing edge of each bank. The shoreline corresponding to this erodible trailing edge will be encroached on by the leading edge of the following mud bank years later. These relatively 'mud-deficient' inter-bank areas are characterized by a deeper foreshore of old bank mud, and the shoreline is composed of either stiff consolidated mud bearing mangroves that may be rapidly eroded, or, more rarely, sandy beaches. The Mana and other rivers in French Guiana drain the Guiana Shield, and thus supply sand-sized sediments that, together with the mud supplied alongshore from the Amazon, have contributed to building up the French Guiana coastal plain. In addition to sand sourcing by the coastal rivers, reworking of old abandoned cheniers inland during prolonged inter-bank phases can also lead to sand releases to the shore. Over the decadal to multi-decadal timescales involved in bank-inter-bank cycles, changes in channel-mouth locations can occur as the mud capes diverting the smaller river mouths during bank phases are eroded. This leads to changes in injection points on the coast of sand reworked from older sand bodies inland (Anthony, Gardel, and Gratiot, 2014). Since mud banks are separated by inter-bank zones having a much less dissipative inner shoreface, inter-bank zones are thus areas of chenier 
formation within this predominantly muddy environment. The formation of cheniers is, therefore, not primarily related to alternations between low wave energy conditions (muddy sedimentation) and high wave energy conditions (chenier formation), as commonly observed on many of the world's chenier coasts, but depends on the alongshore alternations of banks and interbank zones.

The extremely dynamic nature of the Guianas coast renders it particularly pertinent for monitoring shoreline changes at various timescales ranging from weeks to several decades. In particular, it is becoming clear that although mud-bank and inter-bank phases induced by wave-generated bank migration are the overarching drivers of shoreline change, shoreline response can be quite variable in space and time (Anthony et al., 2015). This renders rather tricky efforts in predicting shoreline change based on monitoring and mapping of migrating mud banks and their associated inter-bank zones. The twinned commune of Awala and Yalimapo, in western French Guiana (Figure 1), is a particularly pertinent sector on the Guianas coast for long-term shoreline monitoring of changes affecting the dominantly muddy Amazon-influenced system, and is a workshop site of the French national coastal observation service DYNALIT. The aim of this study is to document multi-decadal shoreline changes at this site in response to the large-scale regional background mud-bank dynamics and the smaller-scale (local) dynamics of the mouth of the Mana River. The lower Mana River has been diverted by the mud cape of Pointe Isère, since at least the mid19th century (Plaziat and Augustinus, 2004), but this cape has undergone significant erosion and reworking over the last 60 years. The implications drawn from the study are important in terms of: (1) understanding the timescales of muddy shoreline erosion and accretion, (2) and sand concentration and segregation in this largely muddy setting. These latter processes are involved in the formation of beaches and cheniers, rare and valuable ecosystems that serve as turtle-nesting sites and as recreation outlets.

\section{METHODS}

\section{Data Sources and Data Processing}

The rapidly changing nature of the Guianas coast and the scale of mud-bank and inter-bank dynamics are such that remote sensing is the most adapted monitoring approach, whatever the timescale (Walcker, Gratiot, and Anthony, 2016). Multi-decadal shoreline change was analyzed from ten very-high resolution $(0.4$ à $1.5 \mathrm{~m})$ aerial photographs selected from a catalogue spanning 56 years, from 1955 to 2012. These included three ortho-photographs and seven photographs in silver-print and digital format. This dataset was supplemented, for the period 2011-2017, by four PLEIADE and SPOT6/7 satellite images of similar high $(50 \mathrm{~cm})$ resolution (Tabl. 1).

Table 1. Inventory of aerial photographs and satellite images used in the study.

\begin{tabular}{|c|c|c|c|c|c|}
\hline Date & Interval (yr) & Type & Resolution (m) & RMS (m) & Source \\
\hline $1955-08-19$ & - & Panchromatic photo & 1.5 & 10.5 & IGN \\
\hline $1976-08-17$ & 4 & Panchromatic photo & 0.5 & 4.5 & IGN \\
\hline 1987-09-06 & 8 & Panchromatic photo & 0.5 & 9.5 & IGN \\
\hline $1999-12-07$ & 12 & Panchromatic photo & 0.6 & 7 & IGN \\
\hline $2001-10-11$ & 2 & Colour orthophoto & 2.5 & - & IGN \\
\hline 2005-09-02 & 4 & Colour photo & 0.5 & 7.5 & IGN \\
\hline $2012-11-13$ & 1 & Colour orthophoto & 0.4 & - & IGN \\
\hline 2014 & 2 & Satellite Pleiade & 0.5 & - & IGN/CNES \\
\hline $3-11 / 2015$ & 1 & Satellite POT6/7 & 0.5 & - & IGN/CNES \\
\hline $2017-05-27$ & 2 & Satelitte Pleiade & 0.5 & - & IGN/CNES \\
\hline
\end{tabular}

We georeferenced the aerial photographs, and adopted the Universal Transverse Mercator zone 22 North on the World Geodetic System 1984 ellipsoid as our project coordinate system. We used the orthorectified map BD Ortho 2001 provided by IGN as the raster target dataset to identify ground control points and to align images. After a simple manual creation of 20 to 50 homologous ground control points, we used the Arcgis tool to automatically create further ground control points. This tool enabled us to obtain hundreds of control points, and to overcome the difficulties involved in identifying visually homologous points. The tool works on the principle of spectral signature and pixel assembly. A second-order polynomial transformation was applied to the images because of the large number of generated ground control points and their even distribution, and to compensate for oblique distortion because of non-nadir photo shooting. After georeferencing, we carried out fusion of photographs to obtain orthomosaics.

In order to quantify shoreline change, we first vectorized the limit between land and sea using two indicators that show good contrast with non-vegetated areas on the images used: the seaward mangrove fringe and beach sand vegetation on cheniers. This delimitation was facilitated by the high resolution of the images. We then conducted statistical analyses of shoreline variations using the Digital Shoreline Analysis System DSAS v4.4 tool with Arcgis (Thieler et al., 2017). We set up a total of 500 transects spaced $50 \mathrm{~m}$ apart and drawn perpendicular to a baseline that followed closely the seaward limit of the mud cape that hitherto diverted the Mana river mouth.

\section{Accuracy of Results}

The accuracy of the derived shoreline changes stems from a combination of errors associated with image resolution $(50 \mathrm{~cm})$, vectorizing $(50 \mathrm{~cm})$, and georeferencing. Since we had numerous images for each date, we calculated the average of the root mean square errors derived from georeferencing of each date, and obtained a global mean for all dates of $8 \mathrm{~m}$. We then combined these three sources of error to obtain a total accuracy of $c .10 \mathrm{~m}$. 


\section{Mud Bank Mapping}

Mud banks are subtidal to intertidal features 10 to $60 \mathrm{~km}$-long and 10 to $30 \mathrm{~km}$-wide. Tidal limits and the shapes of the banks are, however, hard to differentiate from the ambient sediment-charged waters on remote sensing images (Gardel and Gratiot, 2005). Images taken in the dry season, when waters are less charged in sediment, are more suitable for differentiation of intertidal from subtidal zones, as are images taken at low tide, but subtidal extensions of banks cannot be distinguished on images (Anthony, Gardel, and Gratiot, 2014; Walcker, Gratiot, and Anthony, 2016). Radar images are more practical than optical images in delimiting the intertidal zone (Baghdadi et al., 2004). We mapped mud banks using ten low-resolution LANDSAT satellite images, simply with the objective of determining the presence or not of these features over part of the period of analysis. These images are available for the period 1979-2017.

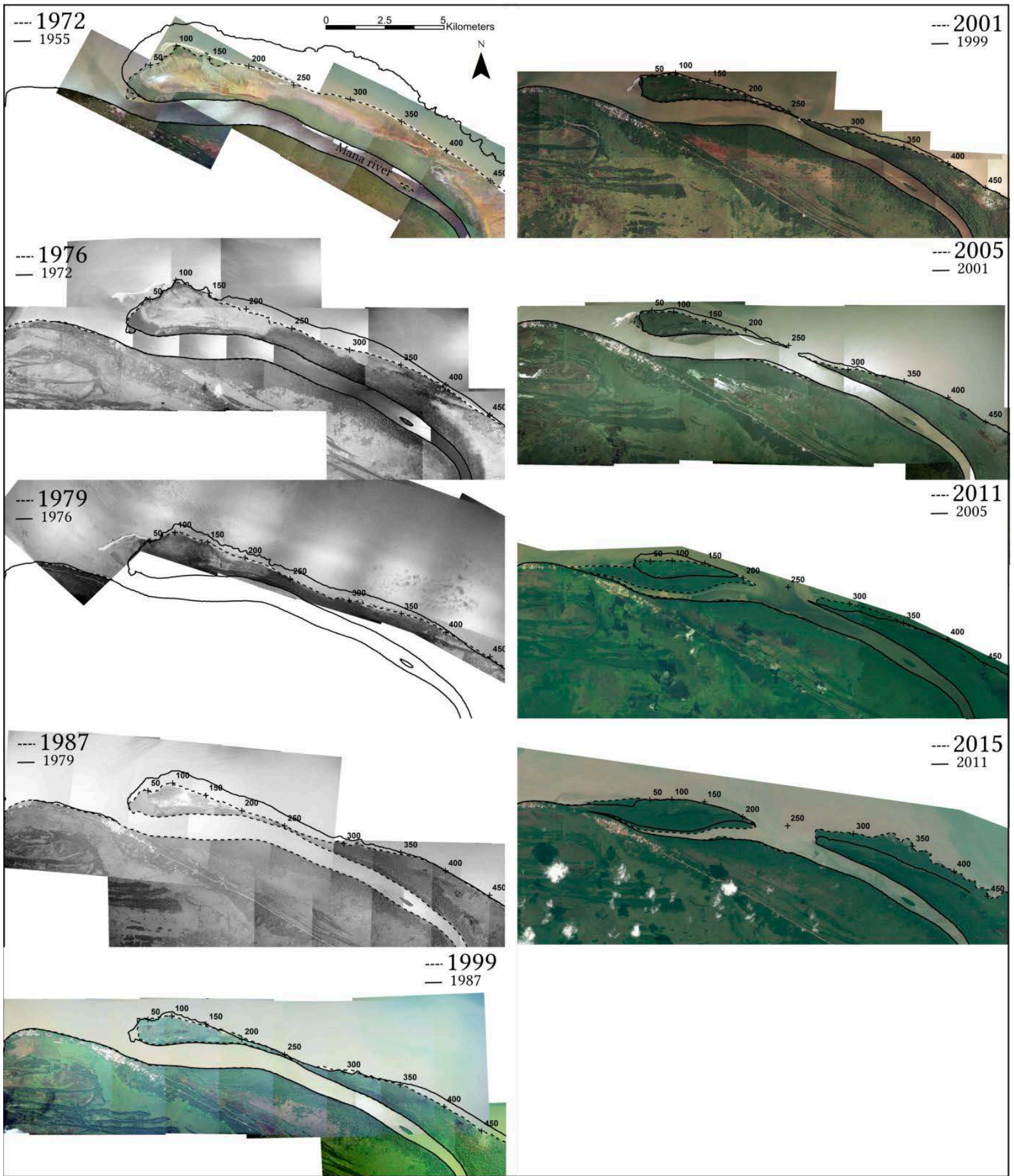

Figure 2. A selection of aerial photographs of the study area from 1955 to 2015, showing the progressive destruction of the mud cape of Pointe Isère, especially rapid between 1955 and 1972, and at about 2001, the breaching of the remnant cape shoreline, leading to a new outlet of the Mana River, followed by subsequent sealing of the former outlet further west. Numbers represent shore-normal transects for the calculation of shoreline change. 


\section{RESULTS}

The results highlight four phases of evolution of the shoreline of Pointe Isère between 1955 and 2017, each characterized by a distinctive trend hinged on erosion rate and shoreline grain size. In the course of these phases, the shoreline indeed showed marked changes in sediment texture, from muddy to sandy, and then muddy. Figure 3 gives an overview of the changes that have characterized the mud cape shoreline over the 60 -year period of analysis. These changes have been quite marked, affecting not only the cape, but also the location of the mouth of the Mana. Quantified rates of retreat are depicted in Figure 3. Between 1955 and 2017, Pointe Isère lost an area of $41.8 \mathrm{~km} 2$. This corresponds to about $8 \%$ of the total area of mangroves in French Guiana in 2015 (Walcker et al., 2015).

The first phase of shoreline evolution, 1955-1972, was characterized by a high rate of retreat involving removal of much of the mud cape and associated mangrove vegetation (Figure 2), resulting in the characteristic irregular shoreline typical of rapid retreat of the muddy Guianas coast (Anthony et al., 2014). The second phase, 1972-2011, was characterized by much more modest erosion, but with variable rates. Two important features of this phase are: (1) the formation of an active sandy chenier with an extending spit, in lieu of the former muddy shoreline (Figure 4), indicating the afore-mentioned first major change in shoreline sediment texture, and (2) breaching, sometime in 2001 (depicted in the 2005 photograph, Figure 2) of the strongly eroded cape, resulting in the formation of a new outlet for the Mana River. By 1987, this actively landward-retreating chenier shoreline had attained an old inland sandy chenier isolated within the mud cape (Figure 4) following the phase of progradation predating the period of analysis. This phase of sandy shoreline retreat, which has resulted in reworking of 1.2 $\mathrm{km}_{2}$ of the old chenier, has been essentially dominated by overwash processes typical of cheniers in this setting (Anthony, Gardel, and Gratiot, 2014). Westward elongation of the hooked spit also occurred (Figure 4) under the influence of longshore transport induced by waves from the northeast. Mud-bank activity over this period appeared to be limited to the distal tip of this new sand spit of Pointe Isère, where significant muddy accretion occurred between 1984 and 1998 (Figure 5). This sector of the study area has since been an area of active mud and sand deposition, and this has culminated in the third phase, in 2011-2015, marked by welding, in the vicinity of Yalimapo, of the remnants of the mud cape and the active chenier and spit, to the terrestrial shoreline downdrift of the former mouth of the Mana (Figure 4c). This welding, downdrift of the 2001 breach, has led to complete sealing of this former river outlet.

This phase has also been characterized by sand transfer from the distal tip of the spit to the welded terrestrial shoreline in a context of erosion between 2005 and 2011, followed by stability. East of Yalimapo, the chenier shoreline underwent variable accretion between 2005 and 2015. Since 2015, much of this shoreline is, however, in erosion, with stability prevailing only in the area of spit welding (Figure 4c). In this area, localized accretion is leading to active seaward translation of the shoreline associated with rapid mud-bank sedimentation and mangrove colonization (Figure 6), inducing a new switch from sandy to muddy shoreline.

\section{DISCUSSION}

The analysis of the remote sensing data on shoreline changes that have affected the mud cape of Pointe Isère in western French Guiana highlights the extreme complexity of the overarching mud-bank and inter-bank system that operates along the Guianas coast. The data reveal four important points: (1) a much longer timescale of continuous erosion on the same stretch of coast than would be expected at the timescale of alongshore migration of mud banks and intervening inter-bank zones (phases), (2) an inference, from point 1 , that the alongshore passage of mud banks does not systematically protect the coast against erosion, (3) important implications in terms of sandy chenier and spit formation, and (4) marked changes in the outlet of the Mana River.

Between 1950 and 1972, the large muddy mangrove-colonized cape diverting the Mana westwards was eroded continuously, notwithstanding the possibility of alongshore migration of several mud banks (that potentially favour accretion). This suggests that conditions were not favourable to further muddy accretion, that timescales of accretion or erosion are not readily predictable (Anthony et al., 2015) and that past large-scale muddy accretion along any sector of the Amazon-influenced coast of the Guianas can switch to a prolonged phase of erosion. The implication is also that the inverse situation can prevail, with stretches of coast subject to prolonged erosion switching over to long-term accretion. The Mana area has successively experienced both these phases, and the current phase of isolation of the active chenier that developed around 1972 (Figure 4) indicates a new cycle of muddy accretion.

By 1972, the prevailing erosion had slowed down considerably in comparison to the previous two decades (Figure 3). The mud and mangrove organic remains were removed alongshore within the framework of the regional east-west transport system. At the same time, residual contemporary sand initially blanketed by mud associated with the cape shoreface, and, later, sand reworked from an old chenier within the cape, was progressively concentrated into an active chenier that evolved into a spit at its distal end (Figure 2). In essence, the muddy shoreline system that existed in this area, and that diverted the Mana since at least the mid-19th century (Plaziat and Augustinus, 2004), had been replaced by a sandy chenier and spit system by 1972 . This reflects the tendency, under long-lasting conditions of exposure to erosion (which, at this timescale, incorporate several bank and inter-bank phases, Figure 5), for the formation of sandy shorelines that are well-adapted to wave-domination of the coastal dynamics of the Guianas. Following erosion of the muddy cape, the sandy chenier system that developed along the waveexposed shoreline retreated landwards, as is classically the case of cheniers on this coast (Anthony, Gardel, and Gratiot, 2014). By 1987, this retreat had attained the old chenier incorporated within the initial mud cape. Reworking of this inland chenier has, in turn, further released sand for the construction of the complex growing spit (Figure 4). At the same time, shoreline retreat finally resulted in breaching of the former wide cape sometime in 2001, resulting in the new outlet of the Mana River (Figure 1). This paved the way for the attachment of the spit to the continental shoreline between 2005 and 2011.

At present, the chenier and its distally attached spit are completely vegetated and fronted by mud that has been colonized by dense mangroves (Figure 6), reflecting a new phase of muddy accretion west of the former mouth of the Mana River. This phase should lead to the formation of a new muddy cape that will progressively re-divert the Mana westwards. 


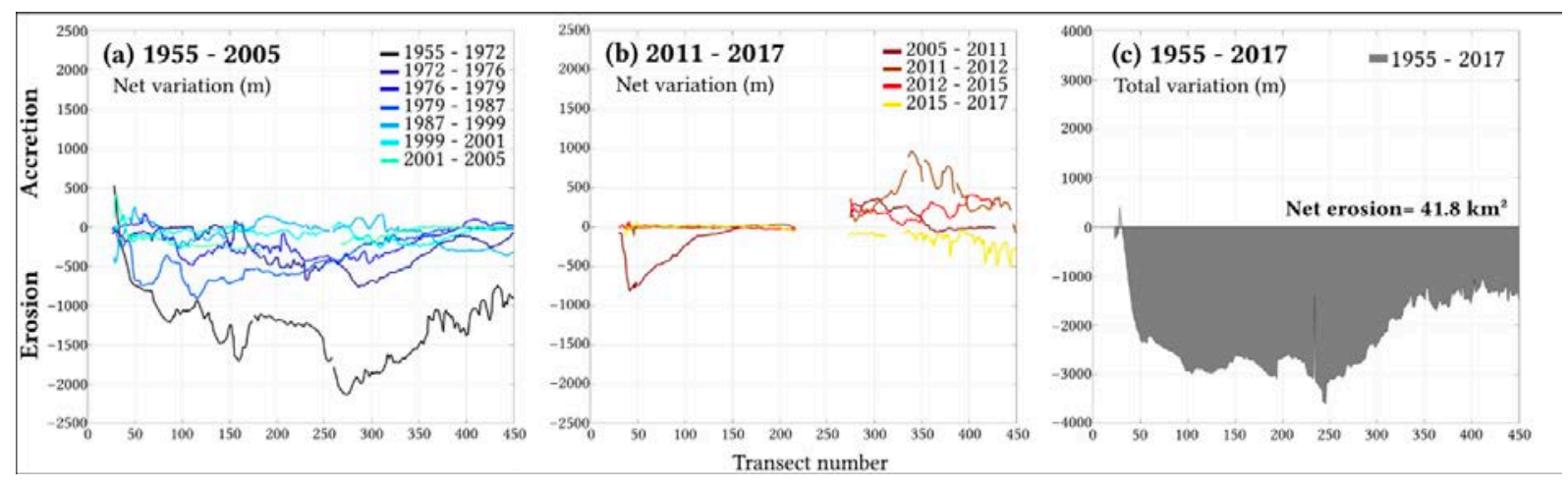

Figure 3. Quantified shoreline variation (a) between 1955 and 2005 and (b) between 2011 and 2017, showing in (c) a total erosion of nearly $42 \mathrm{~km} 2$ of coast, corresponding to the demise of the hitherto 2-3 km-wide muddy cape of

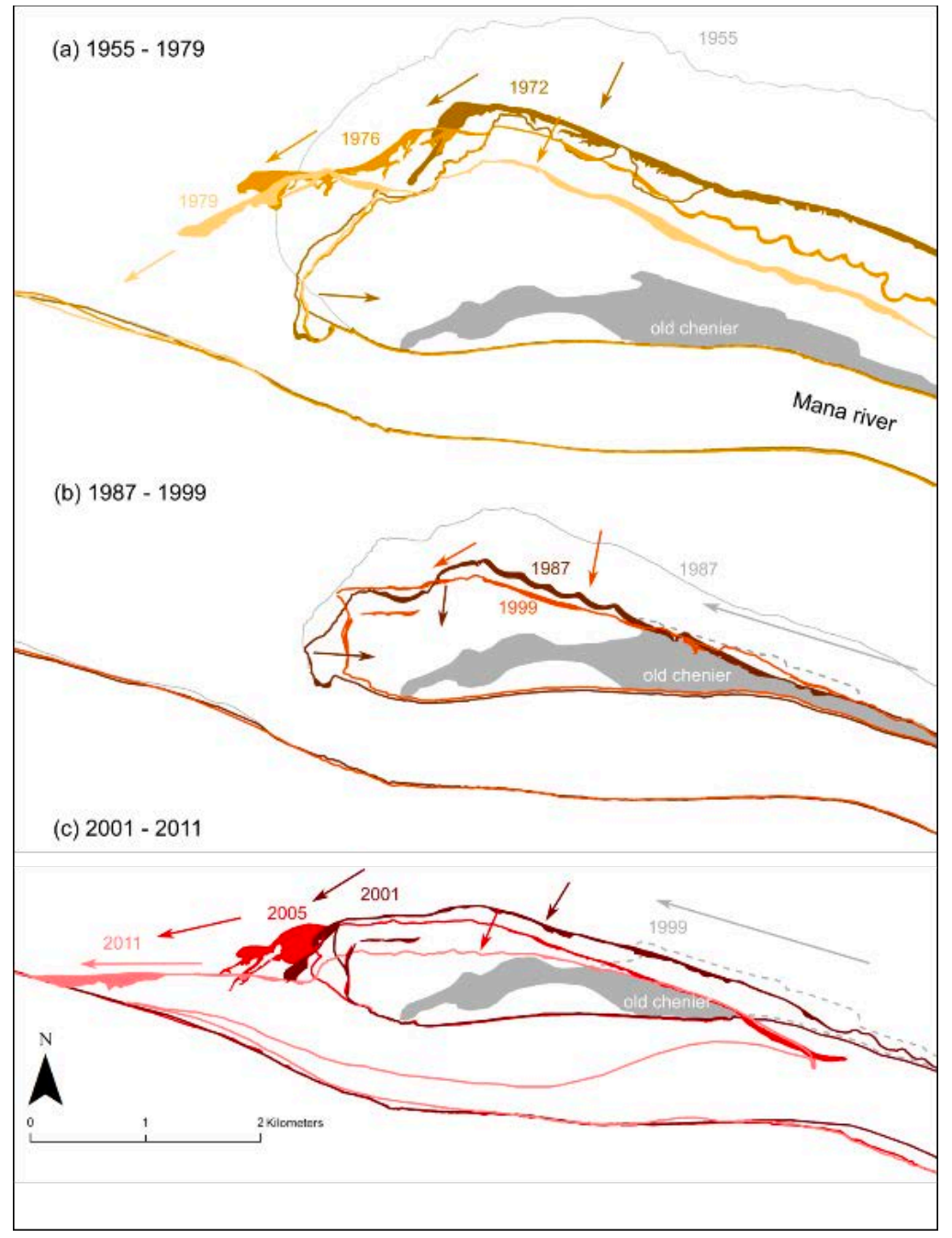

Figure 4. The onset of formation of an active sandy chenier at about 1972, marking a subsequent slow-down in the rate of shoreline retreat, and followed by the development of an actively elongating spit (a). The figure also shows the progressive reworking of an old inland chenier following shoreline erosion and retreat of the active chenier (b) (c). By 2011, the spit had welded onto the terrestrial shoreline, consolidating the sealing of the former outlet of the Mana River estuary (c). 


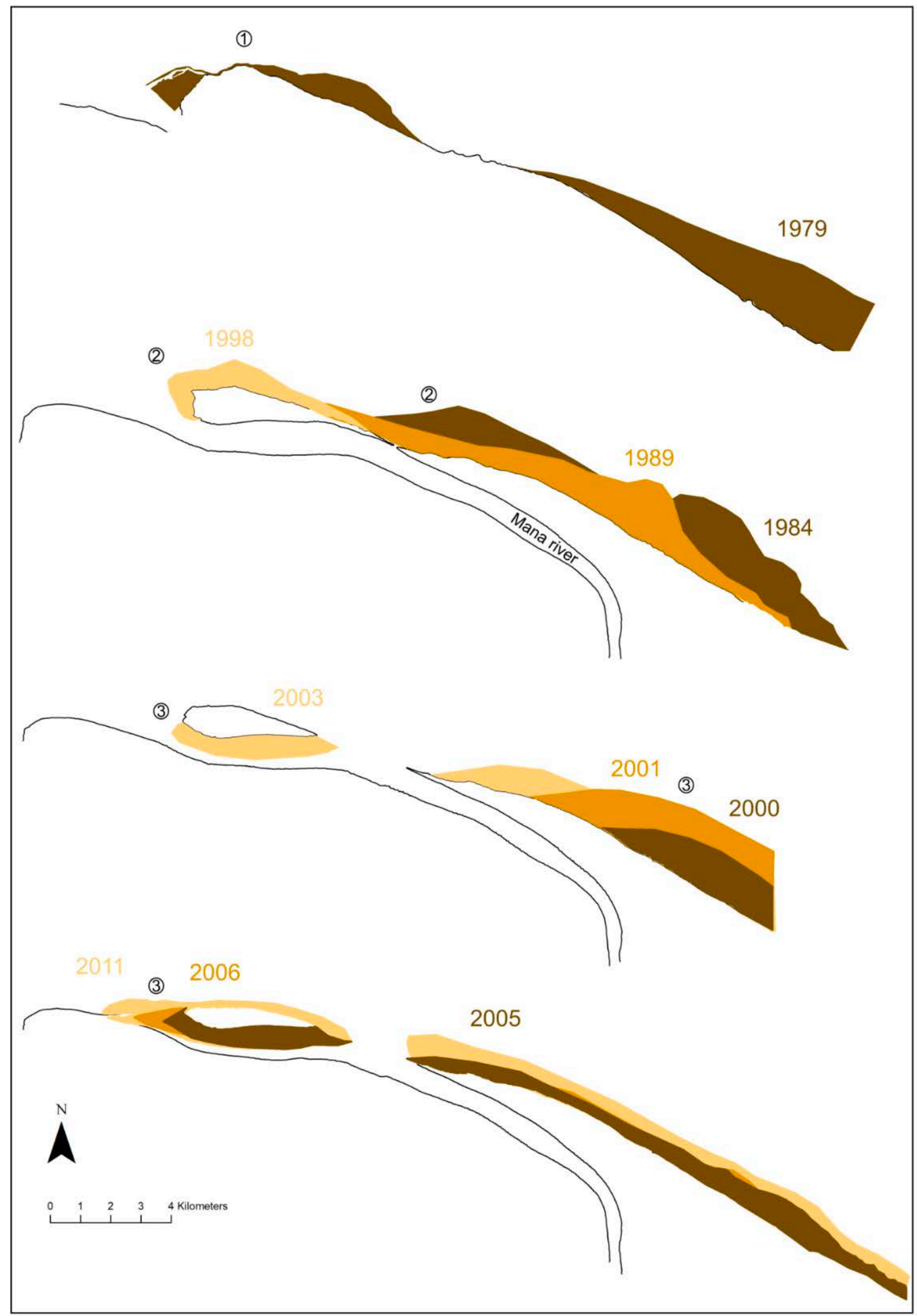

Figure 5. Identified mud banks in migration from 1979 to 2011 . Three banks (numbered 1 to 3 ) were identified from Landsat satellite images: 1 in 1979, 2 between 1984 and 1998, and the trailing edge of 3 between 2005 and 2011. 


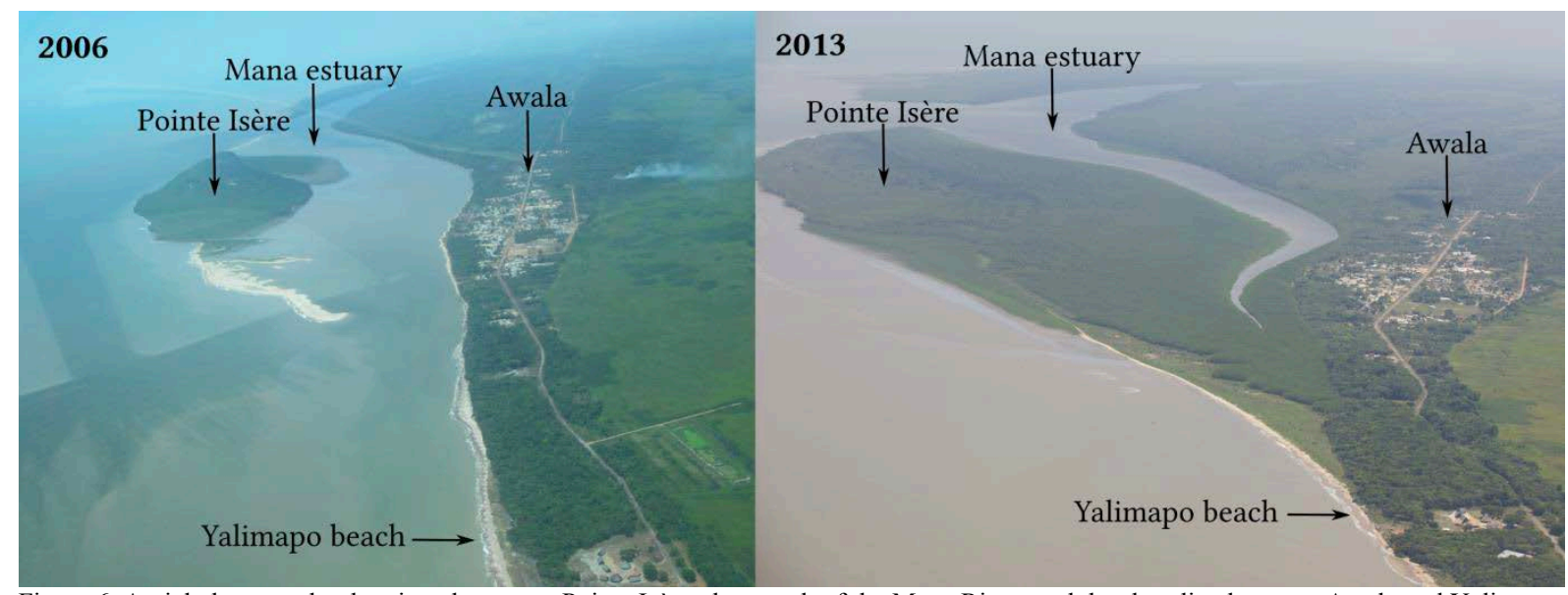

Figure 6. Aerial photographs showing changes to Pointe Isère, the mouth of the Mana River, and the shoreline between Awala and Yalimapo. Note the welding of the spit to the shoreline and colonization, updrift of Yalimapo beach, of the shore-welded part of a mud bank by mangroves. (photo credit: Daniel Payeur).

\section{CONCLUSIONS}

An analysis of multi-decadal shoreline changes in western French Guiana has highlighted the complexity and unpredictability of both patterns of erosion/accretion and timescales of shoreline change. The muddy cape that hitherto diverted the mouth of the Mana River shows a much longer timescale of continuous erosion on the same stretch of coast than would be expected at the timescale of alongshore migration, past this area, of mud banks that promote shoreline accretion, and of intervening interbank zones associated with shoreline retreat. It may be inferred from the foregoing point that the alongshore passage of mud banks is not a guarantee against erosion. This has important implications regarding the predictability of shoreline change on the Guianas coast. Thus far, these changes have been viewed in terms of mud-bank (shoreline accretion) and inter-bank (shoreline erosion) phases that cover timescales of the order of years to a decade. Between 1955 and 2017, the mangrovecolonized mud cape of Pointe Isère lost about $41.8 \mathrm{~km} 2$, which is about $8 \%$ of the total mangrove area in French Guiana in 2015. Continuous erosion of mud inevitably leads to the concentration, by waves, of residual sand deposits on the shoreface and derived from erosion of inland cheniers exposed as a result of shoreline retreat, forming new active cheniers and spits. These sandy cheniers are still subject to inland retreat as they are characterized by limited sand supply and exposed to waves. A new phase of large-scale muddy accretion marks a switch from erosion to accretion, associated with the on-going isolation, within the growing mud feature, of the active sand chenier. This probably heralds a new cycle of mud-cape formation in the vicinity of the mouth of the Mana that will lead to a new westward diversion of this river.

\section{ACKNOWLEDGEMENTS}

We acknowledge financial support from the European Regional Development Fund for the project OYAMAR. Additional funding was provided within the framework of the projects DYALOG and GUIACHENIER supported by the 'Pépinière Interdisciplinaire de Guyane" of the CNRS. This is a contribution from the National Observation Service DYNALIT site of Awala-Yalimapo in western French Guiana, and of the French GDR LIGA research network. Aerial photographs were provided free of charge by the IGN (French National Institute for Geographic and Forest Information), and downloaded from the website https://remonterletemps.ign.fr/. PLEIADE and SPOT 6/7 images were provided by CNES (distribution Spot Image S.A.). LANDSAT images were downloaded from USGS. Morgane Jolivet acknowledges a PhD grant from Université de Guyane. Two reviewers, among whom Toru Tamura, provided valuable comments on the manuscript.

\section{LITERATURE CITED}

Anthony, E.J.; Gardel, A.; Dolique, F.; Brunier, G., and Peron, C., 2015. Chapter 4: Mud banks, sand flux and beach morphodynamics: Montjoly Lagoon beach, French Guiana. In: Robin, M., Maanan, M. (Eds.), Coastal Sediment Fluxes, Coastal Research Library Series 10, Springer, pp. 75-90.

Anthony, E.J.; Gardel, A., and Gratiot, N., 2014. Fluvial sediment supply, mud banks, cheniers and the morphodynamics of the coast of South America between the Amazon and Orinoco river mouths. Geological Society, London, Special Publications, 388, 533-560.

Anthony, E.J.; Gardel, A; Gratiot, N.; Proisy, C.; Allison, M.A.; Dolique, F., and Fromard, F., 2010. The Amazon-influenced muddy coast of South America: A review of mud bank-shoreline. Earth-Science Reviews, 103, 99-121.

Augustinus, P.G.E.F., 1978. The changing shoreline of Surinam (South America). Ph.D. thesis, University of Utrecht.

Augustinus, P.G.E.F., 2004. The influence of the trade winds on the coastal development of the Guianas at various scale levels: a synthesis. Marine Geology, 208, 141-151.

Augustinus, P.G.E.F.; Hazeloff, L., and Kroon, A., 1989. The chenier coast of Suriname: modern and geological development. Marine Geology, 90, 269-281.

Baghdadi, N.; Gratiot, N.; Lefebvre, J.P.; Oliveros, C., and Bourguignon, A., 2004. Coastline and mudbank monitoring in French Guiana: contributions of radar and optical satellite imagery. Canadian Journal of Remote Sensing 30,109-122. Gardel, A. and Gratiot, N., 2005. A satellite image-based method for estimating rates of mud bank migration, French Guiana, South America. Journal of Coastal Research, 21, 720-728. 
Gratiot, N.; Gardel, A., and Anthony, E.J. 2007. Trade-wind waves and mud dynamics on the French Guiana coast, South America: input from ERA-40 wave data and field investigations. Marine Geology, 236, 15-26.

Plaziat, J.C. and Augustinus, P.G.E.F. 2004. Evolution of progradation/erosion along the French Guiana mangrove coast: a comparison of mapped shorelines since the 18th century with Holocene data. Marine Geology, 208, 127-143

Thieler, R.E.; Himmelstoss, E.A.; Zichichi, J.L., and Ergul, A. 2017. The digital shoreline analysis system (dsas) version 4.0: an arcgis extension fo calculating shoreline change (ver. 4.4, July 2017), U.S. Geological Survey Open-File Report, 20081278 .

Walcker, R.; Anthony, E.J.; Cassou, C.; Aller, R.C.; Gardel, A.; Proisy, C.; Martinez, J.M., and Fromard, F., 2015. Control of mangrove abundance by decadal changes in oceanic wave fields. Journal of Biogeography, 42, 2209-2213.

Walcker, R.; Gratiot, N., and Anthony, E.J., 2016. Remote sensing-based monitoring of the muddy mangrove coastline of French Guiana. 2016. In Baghdadi, N., Zribi, M. (Eds.), Observation_des surfaces continentales par Télédétection, Agriculture et forêt, Paris, ISTE Editions, pp. 297-320. 